\title{
CLONING OF THE ZEA MAIZE GENOME DNA SEQUENCES CAPABLE OF AUTONOMOUS REPLICATION IN SACCHAROMYCES CEREVISIAE
}

\section{N. Shulzhenko, V. A. Kordyum}

Institute of Molecular Biology and Genetics

Academy of Sciences of the Ukrainian SSR, Kiev

Sum m a r y

DNA fragments of maize genome functioning as autonomously replicating sequences (ARS) in yeast were inserted into EcoRI-site of plasmid pYF4O bearing the His3 marker of yeast Saccharomyces cerevisiae. Two plasmids with inserts were sclected whicl transsformed strain His- S. cerevisiae LL20(leu2-3leu2-1/his3-11his3-15) into His ${ }^{+}$with a frequency of (1-3) $10^{2}$ transformants per $1 \mu \mathrm{g}$ of plasmid DNA. ARS-plasmids are located in yeast cells in a nonintegrated form, that is confirmed by the isolation of plasmid DNA from them, with which both $E$. coli and $S$. cerevisiae cells are transformed. Size of cloned EcoRI DNA fragments is about $0.8 \mathrm{MD}$.

1. Gorman J. A., Dove W. F. Warren N. Isolation of physarium DNA segments that support autonomous replication in yeast // Mol. and Gen. Genct.-1981,-183, N 2.P. 306-313.

2. Loppes $R$. Claude D. Chloroplast and nuclear DNA fragments from Chlamydomonas promoting high frequency transformation of yeast// Curr. Genet.-1983.-7, N 6.P. 473-480.

3. Characterization of human chromosomal DNA sequences which replicate autonomously in Saccharomyces cerevisiae/J. F. Montiel, C. J. Norbury, M. F. Tuite et al.// Nucl. Acids Res. - 1984.-12, N 2.-P. 1049-1068.

4. Isolation and characterization of sequences from mouse chromosomal DNA with $\Lambda$ RS function in yeasts/G. E. Roth, H. M. Blanton, L. F. Hager, V. A. Zakian//Mol. and Cell. Biol.- 1983.-3, N 11.-P. 1898-1908.

5. Skatrud P. L., Qucener S. W. Cloning of DNA fragment from Cephalosporium acremonium which functions as an autonomous replicalion sequence in veast//Curr. Genet - 1984-8, N 3.- P. 155-163.

6. Molecular cloning of tobacco chromosomal and cliloroplast DNA segments capable of replication in yeast/U. Hirofumi, O. Takeshi, O. Toshifumi et al.//Mol. and Gen. Genet. - 1983. - 192, N 1-2.- P. $1-4$.

7. Chimeric plasmids for cloning of deoxyribonucleic acid sequences in Saccharomyces cerevisiae / R. K. Storms, J. B. McNeil, P. S. Knaudekar et al.// J. Bacteriol.-1979._ N 1.- P. 73-82.

8. Clewell D. B., Helinski D. R. Supercoiled circular DNA-protein complex in Escherichia coli. Purification and induced conversion to an open circular DNA form// Proc. Nat. Acad. Sci. USA - 1969-62, N 6.-P. 1159-1166.

9. Birnboim H.C. Doly J. A rapid alkaline extraction procedure for screening recombinant plasmid DNA// Nucl. Acids Res.-. 1979...- 7, N 6.... P. 1513.

10. Мироиниченко $\Gamma$. П., Дояченко $А$. Ф. Современные методы выделения ДНК из высших растений // Успехи соврсм. биологии.-1981.-91, № 1.-С. 49-60.

Ин-т молекуляр. биологии и генетики АН УССР,

Получено 21.01 .86 Киев

\section{удК 547.963 .3}

\section{ВЫДЕЛЕНИЕ И ХАРАКТЕРИСТИКА ПРЕПАРАТА ИНДИВИДУАЛЬНОЙ ИЗОАКЦЕПТОРНОЙ тРНК Сер ИЗ ПЕЧЕНИ БЫКА}

\section{Л. Г. Калачнюк, Л. А. Козак, М. А. Тукало, Г. Х. Мацука}

Структурно-функциональные исслсдования тРНК из эукариотичсских организмов связаны с трудностью получсния в достаточных количествах гомогенного полинуклеотидпого материала. Обычно для очистки изоакцепторных тРНК животных приходится использовать многостадийные схсмы очистки, что в результате приводит к низкому выходу индивндуальных препаратов [1].

В настоящей работе выделение индивидуальной изоакцепторной тPHK, сер печсни быка, имеющей длинную вариабельную петлю, проведено всего в две стадии с высоким выходом 
Материалы и методы. Прспараты суммарной тРНК получены по методу Брунграбер) [2]. Смесь аминоацил-тРНК-синтетаз (АРСаз) выдсляли нз печсни быка по [3].

Бензонлированную ДЭАЭ-целлюлозу (БД-цел.юлозу) сиптезировали по методу Тенсра [4]. Первую ко.тонку с БД-це.т.пюлозой готовили, как описано в [5], вторуюподобно нсрвой, нск.Іючив ноны $M g^{2}+$ из всех буферных растворов.

Акцепторную активность тРНКсер опрсдсляли по уровню образования ${ }^{14} \mathrm{C}$-серилTPHК прн избытко фермента в ус:товиях рсакцин аминоацилирования [1]

Исчерлывающий гидрогиз тPHK, Сер $\mathrm{T}_{1}$-PHҚазой («Sankyo Со», Япония) проводн.и в $0,01 \mathrm{M}$ трис- $\mathrm{HCl}$, pH 7,5 , прн $20^{\circ} \mathrm{C}, 17$ ษ. В пробу объемом 30 мк.т вносили тРНK, Т,-РНКазу нз расчета 1 ед. активности фермента на 10 мкг тРНК.

Хроматографию олигонуклеотидов $\mathrm{T}_{1}$-PНКазного гидролизата проводили на микржколонках с ДЭАЭ-цел.тю:озой прн $\mathrm{pH} 7,5$ в $7 \mathrm{M}$ мочевине [6] с пепользонанием микроколононного жидкостного хроматографа «Милихром»

В работе испо:ьзовати спедующие реактивы: ${ }^{14} \mathrm{C}$-серин (удельная активность 4,4 ГБк/ммоль, «Chemapol», ЧССР); натрисвую соль ATP («Serva», ФРГ); $\mathrm{MgCl}_{2}, 2$ меркаптоэтано. ( $\left(\right.$ Mercli», $\left.\Phi P^{\top}\right)$; $\mathrm{NaCl}$ осч.

Результаты и обсуждение. Выделение индивидальной сериновой тPНК из печени быка проводити комбннацией двух хроматографий на колонках с БД-целлюлозой. На первой стадин очистки нспользова.ли хроматографию суммарной тРНК на БД-целлюлозе пюо [5].

При хроматографни 1 г суммарного преларата тРНК печени быка в данной систсмс по.лучено три пика серин-акцегторной активности. Фракцин, содержацие псрвый пик (80 мг), объсдиня.ии и осажда.ти синртом (тPHК, Сер).

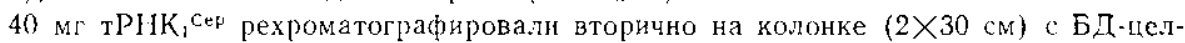
.7ю.7озой в отсутствие нонов $\mathrm{Mg}^{2+}$ при $4^{\circ} \mathrm{C}$. тPHК э.тюнровали со скоростью $55 \mathrm{~m} \pi / \mathrm{u}$ в градиентах концснтраций $0,2-1,3 \mathrm{M} \mathrm{NaCl}(750 \mathrm{~m})$ и 1,3-2,0 $\mathrm{M} \mathrm{NaCl}$ с градиентом этанола от 0 до $10 \%$ (450 мл) в буфере $0,01 \mathrm{M} \mathrm{NaAc,} \mathrm{pH} \mathrm{4,5,} 1$ мM 2-меркаптоэтанол. В пределах первого градиента пронсходила элюция большсй части тPHK. тPHК, Сер, обіладающая, как и тPНК Сер из печени крыс [7], высокой гидрофобностью, элюирова:ась в спиртовом градиенте. В результате хроматографии получено 2 мг тРНК, сер высокой степени чистоты.

Чистоту выделенного препарата проверя.ли по сго акцепторной активности, электрофорезе в полиакриламидном геле $(8 \%)$ в $7 \mathrm{M}$ мочевине, а также по наличию прнмесных олигонуклеотидов в олигонуклеотидной карте $\mathrm{T}_{1}$ - $\mathrm{PHҚазного} \mathrm{гидролизата}$ тPHК, Сер, где найдено очень низкое количество примесных олигонукісотидов. Это свндетельствует о высокой степени чистоты полученного ирспарата.

Таким образом, использованная схема очистки тРНК, сер является зффективной дия препаративного выдстсния тРНК. При ес примснения из 1 г суммарной тРНК выдс.ли:ти 4 мг тРНК, сег с высокой стеленью чистоты, что подтверждено при расинфровке сс первичной структуры. Исходя из полученных прсдваритсльных даных, псрвичная структура тPНК, сер печени быка имеет высокую гомологию с тPHK ${ }_{3}$ сер печсни крыchi $[7]$.

\section{ISOLATION AND CHARACTERISTIC OF THE INDIVIDUAL ISOACCEPTOR IRNA, ser PREPARATION FROM THE BOVINE LIVER}

\section{G. Kalachnyuk, L. A. Kozak, M. A. Tukalo, G. Kh. Matsuka}

Institute of Molecular Biology and Genetics,

Academy of Sciences of the Ukrainian SSR, Kiev

Sum mary

Two stages were applied for high yield isolation of individual isoacceptor serine tRNA from the bovine liver, summing up $4 \mathrm{mg}$ of $\mathrm{tRNA}_{1}{ }^{\text {ser }}$ from $1 \mathrm{~g}$ of total tRNA.

1. Методы выделения суммарных тРНК и иидивндуальных тРНК Лей и тPНК Фен из животных ткансй / М. И. Коваленко, Н. И. Желтовская, А. В. Ельская и др.// Методы молекуляр. биологии.-Кнсв : Наук. думка, 1979.-С. $98-111$.

2. Brungraber E. A. Simplified procedure for preparation of «soluble» RNA from rat liver//Biochem. and Biophys. Res. Communs. $-1962,-8, \mathrm{~N} 1 .-\mathrm{P} .1-3$.

3. Keller E., Zamechnick $P$. The effect of guanosine diphosphate and triphosphate on incorporation of labelled amino acids into proteins $/ / \mathrm{J}$. Biol. Chem. - 1956.-221, N 1.P. $45-49$.

4. The separation of soluble ribonucleic acids on benzolated DEAE-cellulose/J. Gillam, S. Millward, D. Blew et al.// Biochemistry.-1967.-6, N 10.-P. 3043-3048. 
5. Diamond A., Dudock B. Structure and properties of a bovine liver UGA supressor serine tRNA with a triptoplan anticodon // Cell. 1981.-25, N 2.-P. 497-506.

6. Тукало М. А., Васильченко Н. I., Власоя B. В. У:птрамикроспектрофотометрические

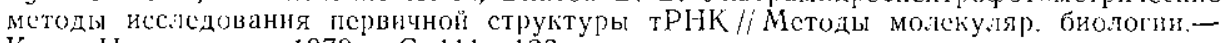
Киев : Наук. думка, 1979-- С. $111-126$.

7. Rogg H., Müller P., Staechelin $M$. Nucleotide sequences of rat liver scrine IRNA. Structure of serine tRNA $A_{3}$ and partial nucleotide sequences of serine tRNA $A_{2 a} / /$ Eur. J. Biochem. - 1975. - 53, N 1.- P. 115-127.

Ин-т молскуляр. биологии и генстики АН УССР, Кнев

Получено 20.02 .87

Y.LK 3 it 212

\title{
ХИМЕРНЫЙ ГЕН RPOC' LACZ $^{\prime}$ РЕКОМБИНАНТНОЙ ПЛАЗМИДЫ рUС19, СОХРАНЯЮШЕЙ ३-ГАЛАКТОЗИДАЗНУЮ АКТИВНОСТЬ B KJIETKAX ESCHERICHIA COLI
}

\author{
Е. Б. Патон, А. Н. Живолуп
}

Пля изучения функциона:ıной топографни основного фсрмента транскрипиии $E$. соli - ДНК-зависнмой РНК-полимсразы - рансе были сконструированы рекомбинантные ннтевндныс фаги $M 13 m p 8$ и $m W B$ [1] и рекомбинантная плазмида $p U C 19$ [2] со ветроегным Bgll/-B-фррагмснтом космиды $p J C 703$ [3], содержащем гены rplJ, rplL и rpoB (кодирующие рибосомные бслкн L10, L7/L12 и $\beta$-субъединичу PHK-полнмеразы), а также участок гена гроС ( $\beta^{\prime}$-субъединица РІІҚ-полимеразы). Было об̆наружено, что при жлонировании в нитевндных векторных фагах встранвание вышеуказанного фрагмента происходит в сдинственной ориентации, так, что направление транскрицции с промоторов lac (всктора) и $P_{y}$ (клонированного фрагмснта) совпадает. При клонировании в плазмнде pUC19 [4] также наблюдалась однонаправленная ориентация [2] встранваемого фрагмента, но она была гротнвоположной его орнентации в ннтевидных фагах [1]. В нервом н во втором случаях при отборе рекомбинантных клонов мы нспользовали то обстоятельство, что встраиванис чужеродного фрагмента ДНК в полилинксрную область вектора нарушает структуру гена lac $Z^{\prime}$. Это приводит к потере голубой окраски на индикаторной среде с ИПТГ (нзопропиттиогалактозид) и X-gal (5-бромо-4-хиоро3-нндолил- $\beta$-D-галактозид) [5] клеткамн, содержапими рекомбинантную ДНК. Известны, однако, случаи $[6,7]$, когда совгадение рамки считывания гела lac $Z^{\prime}$ вектора н гена, содержащегося во ветроенном фрагмснте, может прнвести к образованию гибрндного бслка, сохраняющего способность к $\alpha$-комплементации [8] и обеспечивающего активность $\beta$-галактозидазы, прояв:1яюшуюся в голубой окраске клеток $E$. coli, включающих рекомбннантную ДНК. Из анализа нуклеотидной последовательности плазмнды pUC19 [4] и к:гонруемого Bgll/-B-фрагмснта́ [9-12] ста.ıо очсвндно, что при встранванин последнего в BamHI-сайт полилнкерной областн pUC19 возможно слия-

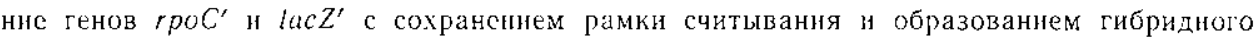
гена (ирн к.тонировании в нитевидных фағах $M 13 m p 8$ и mp9 рамка считывания нарушаетея). Д.ия птроверки этого предпопожения, т. с. возможной а.чьтернативной ориснта-

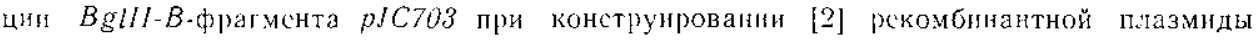
pUC19, результатом которого явилось бы образованне хнмерного гена rpo $C^{\prime}$-lac $Z^{\prime}$, кодирующего способный к $\alpha$-комплсмснтацин химсрный донорный пептид $\beta$-гапактозидазы, мы провсли анализ полученных ранее [2] клонов $E$. coli, обладающих устойчивостьк $к$ ампицнлтину (коднруемой геном вскторной пилазмиды $p U C 19$ ) и голубой окраской на средс, содержащей ИПТГ и Z-gal (Z-gal синтезирован в лабораторни A. Г. Терентьсва, Ин-т молкуляр. биологин и генетики $\Lambda \mathrm{H}$ УССР, и являстя аналогом X-gal). Учитывая, что ген $r p o B$, содержащийся в $B g l / I$-B-фрагменте $p J C 703$ (рис. 1), несет доминантную мутапню устойчивости к рнфамлицину (rifr) rpoB3, голубые клоны $E$. coli, полученныс в результате трансформацин компетентных клеток E. coli JM101 [5] лигазной смесью $B g l l$-гидролнзата $p / C 703$ с Bam/I/-гидролизатом $p U C 19$, перека.тывали на среду, содержацую 100 мкг/мл рнфампицина. В результате этого были отобраны 50 кіонов E. coli, обладающих Rifr-фснотипом и голубой окраской. Далее пюизмидную ДНК из 